\title{
Evaluation of Reproducible and Transparent Research Practices in Pulmonology
}

\section{Publications}

Caleb A. Smith ${ }^{1}$, Johnny Nolan, B.S. ${ }^{2}$, Daniel J. Tritz, B.S. ${ }^{1}$, Trace E. Heavener, D.O.. ${ }^{3}$, Jameson Pelton, D.O. ${ }^{4}$, Kathy Cook, D.O. ${ }^{4}$, and Matt Vassar, Ph.D. ${ }^{1}$

${ }^{1}$ Department of Psychiatry and Behavioral Sciences, Oklahoma State University Center for Health Sciences, Tulsa, Oklahoma

${ }^{2}$ Kansas City University of Medicine and Biosciences, Joplin, Missouri

${ }^{3}$ Department of Medicine, Citizens Memorial Hospital, Bolivar, Missouri

${ }^{4}$ Department of Internal Medicine, Oklahoma State University Medical Center

Correspondence and requests for reprints should be addressed to Caleb A. Smith, Oklahoma

State University Center for Health Sciences, 1111 West 17th Street, Tulsa, Oklahoma 74107.

Email: Caleb.smith12@okstate.edu

Author Contributions: DJT, MV: Substantial contributions to the conception and design of the work. CAS, JN, DJT: Acquisition, analysis, and interpretation of data for the work. CAS, DJT, TEH, JP, KC: Drafted the work and revised it critically for important intellectual content. MV: Final approval of the version submitted for publication. CAS: Accountability for all aspects of the work in ensuring that questions related to the accuracy or integrity of any part of the work are appropriately investigated and resolved.

Funding Statement: This study was funded through the 2019 Presidential Research Fellowship Mentor - Mentee Program at Oklahoma State University Center for Health Sciences.

Running Head: Reproducibility of Pulmonology Publications 


\begin{abstract}
Rationale - Study reproducibility is valuable for validating or refuting results. Provision of reproducibility indicators, such as materials, protocols, and raw data in a study to improve its potential for reproduction. Efforts to reproduce noteworthy studies in the biomedical sciences have resulted in an overwhelming majority of them being found to be unreplicable, causing concern for the integrity of research in other fields, including medical specialities.

Objective - Here, we analyzed the reproducibility of studies in the field of pulmonology. Methods - 300 pulmonology articles were randomly selected from an initial PubMed search for data extraction. Two authors scoured these articles for reproducibility indicators including materials, protocols, raw data, analysis scripts, inclusion in systematic reviews, and citations by replication studies as well as other factors of research transparency including open accessibility, funding source and competing interest disclosures, and study preregistration.

Main Results - Few publications included statements regarding materials (11\%), protocols (1\%), data (21\%), and analysis script (0\%) availability. Less than $10 \%$ indicated preregistration. More than half of the publications analyzed failed to provide a funding statement. Conversely, $66 \%$ of the publications were open access and 70\% included a conflict of interest statement.

Conclusion - Overall, our study indicates pulmonology research is currently lacking in efforts to increase replicability. Future studies should focus on providing sufficient information regarding materials, protocols, raw data, and analysis scripts, among other indicators, for the sake of clinical decisions that depend on replicable or refutable results from the primary literature.
\end{abstract}

\title{
Abstract Word Count: 250
}

Key words: Reproducibility of results, Evidence-based medicine, Pulmonology 


\section{Introduction}

Reproducibility — the ability to duplicate a study's results using the same materials and methods as the original investigator-is central to the scientific method(1). Study reproducibility establishes confidence in the efficacy of therapies, while results that contradict original findings may lead to overturning previous standards. Herrera-Perez et al. recently evaluated 396 medical reversals in which suboptimal clinical practices were overturned when randomized controlled trials yielded results contrary to current practices(2). Given the evolving nature of evidence-based patient care, studies must be conducted in a way that fosters reproducibility and transparency. Further, materials, protocols, analysis scripts, and patient data must be made available to enable verification.

Efforts supporting reproducibility are becoming more widespread owing to the open science movement. In 2013, the Center for Open Science was established to "increase the openness, integrity, and reproducibility of scientific research"(3). The center sponsored two large-scale reproducibility efforts: a series of 100 replication attempts in psychology and a series of 50 landmark cancer biology study replication attempts. In the first, investigators successfully reproduced only $39 \%$ of the original study findings(4). In the second, efforts were halted after only 18 replications because of lack of information and materials from authors, insufficient funding, and insufficient time to perform all the experiments(5). The center also created the Open Science Framework, a repository in which authors may deposit study protocols, participant data, analysis scripts, and other materials needed for study reproduction. More recently, the center created Transparency and Openness Promotion Guidelines, which include eight 
transparency standards and provides guidance for funders and journals, and initiated the use of badges for journals that adopt reproducible practices.

Current estimates of study reproducibility are alarming. In the biomedical sciences, reproducibility rates may be as low as $25 \%$ (6). One survey of 1576 scientists found that $90 \%$ of respondents believed science was experiencing a reproducibility crisis; $70 \%$ reported not being able to reproduce another investigator's findings, and more than half reported an inability to reproduce their own findings(7). The picture is even less clear in the clinical sciences. Ioannidis found that of 49 highly cited original research publications, seven were refuted by newer studies, and seven suggested higher efficacy than follow-up results; only 22 were successfully replicated(8). The National Institutes of Health and the National Science Foundation have responded to this crisis by taking measures to ensure that studies funded by tax dollars are more reproducible. However, little is known about the extent to which reproducibility practices are used in clinical research.

In this study, we evaluated reproducible and transparent research practices in the pulmonology literature(9). Our goals were (i) to determine areas of strength and weakness in current use of reproducible and transparent research practices and (ii) to establish a baseline for subsequent investigations of the pulmonology literature.

\section{Methods}


This observational study employed a cross-sectional design. We used the methodology of Hardwicke et al.(9), with modifications. In reporting this study, we follow the guidelines for meta-epidemiological methodology research(10) and the Preferred Reporting Items for Systematic Reviews and Meta-analyses (PRISMA)(11). This study did not satisfy the regulatory definition for human subjects research as specified in the Code of Federal Regulations and therefore was not subject to institutional review board oversight. We have listed our protocol, materials, and data on Open Science Framework (https://osf.io/n4yh5/).

\section{Journal and Publication Selection}

The National Library of Medicine catalog was searched by DT using the subject terms tag "Pulmonary Medicine[ST]” to identify pulmonary medicine journals on May 29, 2019. To meet inclusion criteria, journals had to be published in English and be MEDLINE indexed. We obtained the electronic ISSN (or linking ISSN) for each journal in the NLM catalog meeting inclusion criteria. Using these ISSNs, we formulated a search string and searched PubMed on May 31, 2019, to locate publications published between January 1, 2014, to December 31, 2018. We then randomly selected 300 publications for data extraction using Excel's random number function (https://osf.io/zxjd9/).

\section{Extraction Training}

Prior to data extraction, two investigators (JN, CS) underwent training to ensure inter-rater reliability. The training included an in-person session to review the study design, protocol, Google form, and location of the extracted data elements in two publications. The investigators 
were next provided with three additional publications from which to extract data. Afterward, the pair reconciled differences by discussion. This training session was recorded and deposited online for reference (https://osf.io/tf7nw/). Prior to extracting data from all 300 publications, the two investigators extracted data from the first 10 , followed by a final consensus meeting. Data extraction for the remaining 290 publications followed, and a final consensus meeting was held to resolve disagreements. A third author (DT) was available for adjudication, if necessary.

\section{Data Extraction}

The two investigators extracted data from the 300 publications in a duplicate and blinded fashion. A pilot-tested Google form was created from Hardwicke et al.(9), with additions (see Table 1 for a description of the indicators of reproducibility and transparency). This form prompted coders to identify whether a study had important information that needed to be reproducible (https://osf.io/3nfa5/). The extracted data varied by study design. Studies without empirical data (e.g., editorials, commentaries [without reanalysis], simulations, news, reviews, and poems) had only the publication characteristics, conflict of interest statement, financial disclosure statement, funding sources, and open access availability. We catalogued the most recent year and 5-year impact factor of the publishing journals. We also included the following study designs: cohort, case series, secondary analysis, chart review, and cross-sectional. Finally, we expanded the funding options to include university, hospital, public, private/industry, or nonprofit. 
We used Open Access Button (http://www.openaccessbutton.org) to identify publications as being publicly available. Both the journal title and DOI were used in the search to mitigate chances of missing an article. If Open Access Button could not locate an article, we searched Google and PubMed to confirm open access status.

\section{Publication Citations Included in Research Synthesis and Replication}

For empirical studies, Web of Science was used to identify whether the publication was replicated in other studies and had been included in systematic reviews and/or meta-analyses. To accomplish these tasks, two investigators $(\mathrm{CS}, \mathrm{JN})$ inspected the titles, abstracts, and introductions of all publications in which the reference study was cited. This process was conducted in a duplicate, blinded fashion.

\section{Data Analysis}

We used Microsoft Excel to calculate descriptive statistics and 95\% confidence intervals (95\% CIs). 


\section{Results}

Study Selection and Article Accessibility

Our PubMed search identified 299,255 publications. Limiting our search to articles published from January 1, 2014, to December 31, 2018, yielded 72,579 publications, from which 300 were randomly selected. Of these 300 publications, 194 were open access and 106 were behind a paywall. Eight publications could not be accessed by investigators and were thus excluded, leaving 292 for further analysis (Figure 1). Characteristics of the included publications can be found in Table 2.

\section{Availability of Reproducibility Indicators}

Figure 2 depicts an overview of our study results. A total of 150 empirical studies (excluding 30 case studies/case series and two meta-analyses) were evaluated for material availability. The majority of studies offered no statement regarding availability of materials $(n=133 ; 88.67 \%$ [95\% CI, 85.08\%-92.25\%]). Sixteen studies (10.67\% [7.17\%-14.16\%]) had a clear statement regarding the availability of study materials. One study $(0.67 \%[0 \%-1.59 \%])$ included an explicit statement that the materials were not publicly available. Ten of the 16 materials files were accessible; the remaining four either led to a broken URL link or a pay-walled request form.

A total of 152 empirical studies (excluding 30 case studies/case series) were assessed for availability of protocols, raw data, and analysis scripts. Two studies provided access to a protocol $(1.32 \%[0.03 \%-2.61 \%])$. Data availability statements were more common, with 31 
studies $(20.39 \%$ [15.84\%-24.95\%]) including a statement that at least partial data were available. Analysis scripts were not found in a single study. More information on these metrics is presented in Supplemental Table 1.

\section{Study Preregistration}

A total of 152 empirical studies (excluding 30 case studies/case series) were searched for a statement regarding study preregistration. Few studies included statements: $14(9.21 \%$ $[5.94 \%-12.48 \%])$ declared preregistration, while three $(1.97 \%[0.40 \%-3.55 \%])$ explicitly disclosed that they were not pre-registered. More information on preregistration is presented in Supplemental Table 1.

\section{Study Replication and Citation Analysis}

Of 152 empirical studies analyzed, only one $(0.66 \%[0 \%-1.57 \%])$ reported replication of the methods of a previously published study. No studies were cited by a replication study. A total of 180 of the 182 empirical studies (excluding two meta-analyses) were evaluated to determine whether any had been included in a systematic review. Thirteen studies $(7.22 \%$ $[4.29 \%-10.15 \%])$ were cited once in a systematic review or meta-analysis, 11 studies $(6.11 \%$ $[3.40 \%-8.82 \%])$ were cited in two to five systematic reviews or meta-analyses, and one study $(0.56 \%[0 \%-1.40 \%])$ was cited in more than five systematic reviews or meta-analyses. One study $(0.56 \%[0.55 \%-0.55 \%])$ was explicitly excluded from a systematic review.

\section{Conflict of Interest and Funding Disclosures}


All 292 publications were assessed for their inclusion of a conflict of interest statement and/or a funding statement. A majority $(n=207 ; 70.89 \%)$ included a conflict of interest statement, with 157 declaring no competing interests (53.77\% [48.13\%-59.41\%]). More than half of the publications failed to provide a funding statement $(n=164 ; 56.16 \%$; Table 3$)$. In publications with a funding statement, public funding was the most common source $(n=37 ; 12.67 \%)$.

\section{Discussion}

In this cross-sectional review of pulmonology publications, a substantial majority failed to provide materials, participant data, or analysis scripts. Many were not preregistered and few had an available protocol. Reproducibility has been viewed as an increasingly troublesome area of study methodology(12). Recent attempts at reproducing preclinical $(13,14)$ and clinical studies have found that only $25 \%-61 \%$ of studies may be successfully reproduced $(6,15)$. Many factors contribute to limited study reproducibility, including poor (or limited) reporting of study methodology, prevalence of exaggerated statements, and limited training on experimental design in higher education(16). In an effort to limit printed pages and increase readability, journals may request that authors abridge methods sections(17). Here, we briefly comment on selected indicators to present a balanced view of the perspectives of those in favor of reproducibility and transparency and those who resist enacting such changes.

First, data sharing allows for the independent verification of study results or reuse of that data for subsequent analyses. Two sets of principles exist. The first, known as FAIR, outlines mechanisms for findability, accessibility, interoperability, and reusability. FAIR principles are 
intended to apply to study data as well as the algorithms, tools, and workflows that led to the data. FAIR advocates that data be accessible to the right people, in the right way, and at the right time(18). A second set of principles relate to making data available to the public for access, use, and share without licenses, copyrights, or patents(19). While we advocate for data sharing, we recognize that it is a complex issue. First, the process for making data available for others' use requires skills. Further, the process, which includes the construction of data dictionaries and data curation, is time consuming. Furthermore, concerns exist with regard to unrestricted access to data facilitating a culture of "research parasites," a term coined by Drazen and Longo(20) that suggests that secondary researchers might exploit primary research data for publication. Drazen and Longo also cautioned that secondary authors might not understand the decisions made when defining parameters of the original investigations. Finally, the sensitive nature of some data causes concern among researchers.

Second, preregistering a study requires authors to provide their preliminary protocol, materials, and analysis plan in a publicly available website. The most common websites used by authors are ClinicalTrials.gov and the International Clinical Trial Registry Platform hosted by the World Health Organization. These registries improve the reliability and transparency of published findings by preventing selective reporting of results, preventing unnecessary duplication of studies, and providing relevant material to patients that may enroll in such trials(21). The Food and Drug Administration (FDA) Amendments Act and the International Committee of Medical Journal Editors (ICMJE) have both required registration of clinical trials prior to initiation of a study $(22,23)$. Selective reporting bias, which includes demoting primary endpoints, omitting 
endpoints, or upgrading secondary endpoints in favor of statistical significance, may be especially pervasive and problematic. Numerous studies across several fields of medicine have evaluated the extent and magnitude of the problem (24-26). The consequences of selective reporting bias and manipulation of endpoints may compromise clinical decision making. Another issue — $p$-hacking — occurs when researchers repeatedly analyze study data until they achieve statistically significant results. Preregistration of protocols and statistical analysis plans can be used to fact check published papers to ensure that any alterations made in the interim were made for good reason.

Third, transparency related to study funding and financial conflicts of interest should be emphasized. In a previous study, we found that one-third of the authors of pivotal oncology trials underlying FDA drug approvals failed to adequately disclose personal payments from the drug sponsor(27). Recent news accounts of a prominent breast cancer researcher who failed to disclose financial relationships with pharmaceutical companies in dozens of publications has heightened awareness of the pervasiveness of this issue(28). The ICMJE considers willful nondisclosure of financial interests to be a form of research misconduct(29). It is critical that the public be able to adequately evaluate financial relationships of the authors of the published studies in order to evaluate the likelihood of biased results and conclusions.

Several changes are needed to establish a culture of reproducibility and transparency. First, increased awareness of and training about these issues are needed. The National Institutes of Health has funded researchers to produce training and materials, which are available on the 
Rigor and Reproducibility Initiative website(30), but more remains to be done. Strong mentorship is necessary to encourage trainees to adopt and incorporate reproducible research practices. Research on mentorship programs has found that trainees who have mentors report greater satisfaction with time allocation at work and increased academic self-efficacy compared with trainees without a mentor(31). Conversely, poor mentorship can reinforce poor research practices among junior researchers, such as altering data to produce positive results or changing how results are reported(32). Other research stakeholders must be involved as well. Although many journals recommend the use of reporting guidelines for various study designs, such as CONSORT and PRISMA, evidence suggests that these guidelines are not followed by authors or enforced by journals(33). When journals enforce adherence to reporting guidelines, the completeness of reporting is improved(34). Detractors of reporting guidelines are concerned that certain checklists (CONSTORT, STROBE, STARD) will be used to judge research quality rather than improve writing clarity, that editors and peer reviewers will fail to enforce these guidelines, and that insufficient research exists to evaluate the outcomes from applying these guidelines(35).

Our study has both strengths and limitations. We randomly sampled a large number of pulmonology journals containing various types of publications to generalize our findings across the specialty. Our study design also used rigorous training sessions and a standardized protocol to increase the reliability of our results. In particular, our data extraction process, which involved blinded and duplicate extraction by two investigators, is the gold standard systematic review methodology and is recommended by the Cochrane Collaboration(36). We have made all study materials available for public review to enhance the reproducibility of this study. Regarding 
limitations, our inclusion criteria for journals (i.e., published in English and MEDLINE indexed) potentially removed journals that contained more lax recommendations regarding indicators of reproducibility and transparency. Furthermore, although we obtained a random sample of publications for analysis, our sample may not have been representative of all pulmonology publications. Our results should be interpreted in light of these strengths and limitations.

In conclusion, our study of the pulmonology literature found that reproducible and transparent research practices are not being incorporated into research. Sharing of study artifacts, in particular, needs improvement. The pulmonology research community should seek to establish norms of reproducible and transparent research practices.

\section{References}

1. Goodman SN, Fanelli D, Ioannidis JPA. What does research reproducibility mean? Sci Transl Med 2016;8:341ps12.

2. Herrera-Perez D, Haslam A, Crain T, Gill J, Livingston C, Kaestner V, Hayes M, Morgan D, Cifu AS, Prasad V. Meta-Research: A comprehensive review of randomized clinical trials in three medical journals reveals 396 medical reversals. Elife 2019;8:e45183.

3. Triple W. Our Mission. 2006; at <https://cos.io/about/mission/>.

4. Anderson CJ, Anderson J, van Assen MALM, Attridge PR, Attwood A, Axt J, Babel M, Bahník Š, Baranski E, Barnett-Cowan M, Bartmess E, Beer J, Bell R, Bentley H, van den Bergh D, Beyan L, den Bezemer B, Borsboom D, Bosch A, Bosco F, Bowman S, Brandt M, Braswell EL, Brohmer H, Brown BT, Brown K, Brüning J, Calhoun-Sauls A, Callahan S, et 
al. Reproducibility Project: Psychology. 2018;doi:10.17605/OSF.IO/EZCUJ.

5. Reproducibility Project: Cancer Biology. 2013; at <https://osf.io/e81xl/wiki/home/>.

6. Prinz F, Schlange T, Asadullah K. Believe it or not: how much can we rely on published data on potential drug targets? Nat Rev Drug Discov 2011;10:712.

7. Baker M. 1,500 scientists lift the lid on reproducibility. Nature 2016;533:452-454.

8. Ioannidis JPA. Contradicted and initially stronger effects in highly cited clinical research. JAMA 2005;294:218-228.

9. Hardwicke TE, Wallach JD, Kidwell M, Ioannidis J. An empirical assessment of transparency and reproducibility-related research practices in the social sciences (2014-2017). 2019;doi:10.31222/osf.io/6uhg5.

10. Murad MH, Wang Z. Guidelines for reporting meta-epidemiological methodology research. Evid Based Med 2017;22:139-142.

11. Liberati A, Altman DG, Tetzlaff J, Mulrow C, Gøtzsche PC, Ioannidis JPA, Clarke M, Devereaux PJ, Kleijnen J, Moher D. The PRISMA statement for reporting systematic reviews and meta-analyses of studies that evaluate health care interventions: explanation and elaboration. J Clin Epidemiol 2009;62:e1-34.

12. Nosek BA, Spies JR, Motyl M. Scientific Utopia: II. Restructuring Incentives and Practices to Promote Truth Over Publishability. Perspect Psychol Sci 2012;7:615-631.

13. Munafò MR. Reliability and replicability of genetic association studies. Addiction 2009;104:1439-1440.

14. Button KS, Ioannidis JPA, Mokrysz C, Nosek BA, Flint J, Robinson ESJ, Munafò MR. Power failure: why small sample size undermines the reliability of neuroscience. Nat Rev 
Neurosci 2013;14:365-376.

15. Open Science Collaboration. PSYCHOLOGY. Estimating the reproducibility of psychological science. Science 2015;349:aac4716.

16. Carp J. The secret lives of experiments: methods reporting in the fMRI literature. Neuroimage 2012;63:289-300.

17. Marcus E, whole Cell team. A STAR Is Born. Cell 2016;166:1059-1060.

18. Wilkinson MD, Dumontier M, Aalbersberg IJJ, Appleton G, Axton M, Baak A, Blomberg N, Boiten J-W, da Silva Santos LB, Bourne PE, Bouwman J, Brookes AJ, Clark T, Crosas M, Dillo I, Dumon O, Edmunds S, Evelo CT, Finkers R, Gonzalez-Beltran A, Gray AJG, Groth P, Goble C, Grethe JS, Heringa J, 't Hoen PAC, Hooft R, Kuhn T, Kok R, et al. The FAIR Guiding Principles for scientific data management and stewardship. Sci Data 2016;3:160018.

19. What is the difference between "FAIR data" and "Open data" if there is one? - GO FAIR. GO FAIR at <https://www.go-fair.org/faq/ask-question-difference-fair-data-open-data/>.

20. Longo DL, Drazen JM. More on Data Sharing. N Engl J Med 2016;374:1896-1897.

21. of Medical Journal Editors IC, Others. Recommendations for the conduct, reporting, editing, and publication of scholarly work in medical journals. 2016;

22. Food, Administration D, Act FA, Others. of 2007, public law no. 110-85 \S. Last update 2007

23. Laine C, Horton R, DeAngelis CD, Drazen JM, Frizelle FA, Godlee F, Haug C, Hébert PC, Kotzin S, Marusic A, Sahni P, Schroeder TV, Sox HC, Van Der Weyden MB, Verheugt FWA. Clinical Trial Registration — Looking Back and Moving Ahead. New England 
Journal of Medicine 2007;

24. You B, Gan HK, Pond G, Chen EX. Consistency in the analysis and reporting of primary end points in oncology randomized controlled trials from registration to publication: a systematic review. J Clin Oncol 2012;30:210-216.

25. Mathieu S, Boutron I, Moher D, Altman DG, Ravaud P. Comparison of registered and published primary outcomes in randomized controlled trials. JAMA 2009;302:977-984.

26. Rankin J, Ross A, Baker J, O’Brien M, Scheckel C, Vassar M. Selective outcome reporting in obesity clinical trials: a cross-sectional review. Clin Obes 2017;7:245-254.

27. Wayant C, Turner E, Meyer C, Sinnett P, Vassar M. Financial Conflicts of Interest Among Oncologist Authors of Reports of Clinical Drug Trials. JAMA Oncol 2018;4:1426-1428.

28. Ornstein C, Thomas K. Top Cancer Researcher Fails to Disclose Corporate Financial Ties in Major Research Journals. The New York Times 2018;at $<$ https://www.nytimes.com/2018/09/08/health/jose-baselga-cancer-memorial-sloan-kettering .html>.

29. ICMJE | Recommendations | Author Responsibilities-Conflicts of Interest. at $<$ http://icmje.org/recommendations/browse/roles-and-responsibilities/author-responsibilities --conflicts-of-interest.html>.

30. Training. National Institutes of Health (NIH) 2015;at $<$ https://www.nih.gov/research-training/rigor-reproducibility/training >

31. Feldman MD, Arean PA, Marshall SJ, Lovett M, O'Sullivan P. Does mentoring matter: results from a survey of faculty mentees at a large health sciences university. Med Educ Online 2010;15.: 
32. Boulbes DR, Costello T, Baggerly K, Fan F, Wang R, Bhattacharya R, Ye X, Ellis LM. A Survey on Data Reproducibility and the Effect of Publication Process on the Ethical Reporting of Laboratory Research. Clin Cancer Res 2018;24:3447-3455.

33. Sims MT, Checketts JX, Wayant C, Vassar M. Requirements for trial registration and adherence to reporting guidelines in critical care journals: a meta-epidemiological study of journals' instructions for authors. Int J Evid Based Healthc 2018;16:55-65.

34. Agha RA, Fowler AJ, Limb C, Whitehurst K, Coe R, Sagoo H, Jafree DJ, Chandrakumar C, Gundogan B. Impact of the mandatory implementation of reporting guidelines on reporting quality in a surgical journal: A before and after study. Int J Surg 2016;30:169-172.

35. Vandenbroucke JP. STREGA, STROBE, STARD, SQUIRE, MOOSE, PRISMA, GNOSIS, TREND, ORION, COREQ, QUOROM, REMARK... and CONSORT: for whom does the guideline toll? J Clin Epidemiol 2009;62:594-596.

36. Higgins JPT, Green S. Cochrane Handbook for Systematic Reviews of Interventions. John Wiley \& Sons; 2011

Table 1: Indicators of Reproducibility

\begin{tabular}{|l|l|l|}
\hline \multicolumn{1}{|c|}{ Reproducibility Indicator } & \multicolumn{1}{c|}{$\begin{array}{c}\text { Role in producing } \\
\text { transparent and } \\
\text { reproducible science }\end{array}$} \\
\hline Articles & Number of studies & $\begin{array}{l}\text { Widely accessible articles } \\
\text { increase transparency }\end{array}$ \\
\hline Availability of article (paywall or public access) & All (n=300) & $\begin{array}{l}\text { Disclosure of possible sources } \\
\text { of bias }\end{array}$ \\
\hline Funding & All included studies $(\mathrm{n}=292)$ \\
\hline Statement of funding sources & \multicolumn{3}{|l}{} \\
\hline Conflict of Interest & All included studies $(\mathrm{n}=292)$ & $\begin{array}{l}\text { Disclosure of possible sources } \\
\text { of bias }\end{array}$ \\
\hline Statement of competing interests & \\
\hline Evidence Synthesis
\end{tabular}




\begin{tabular}{|c|c|c|}
\hline Citations in systematic reviews or meta-analyses & $\begin{array}{l}\text { Empirical studies excluding } \\
\text { systematic reviews and } \\
\text { meta-analyses }(\mathrm{n}=180)\end{array}$ & $\begin{array}{l}\text { Evidence of similar studies } \\
\text { being conducted }\end{array}$ \\
\hline \multicolumn{3}{|l|}{ Protocols } \\
\hline $\begin{array}{l}\text { Availability statement, and if available, what } \\
\text { aspects of the study are included }\end{array}$ & $\begin{array}{l}\text { Empirical studies excluding } \\
\text { case studies }(\mathrm{n}=152)\end{array}$ & $\begin{array}{l}\text { Availability of methods and } \\
\text { analysis needed to replicate } \\
\text { study }\end{array}$ \\
\hline \multicolumn{3}{|l|}{ Materials } \\
\hline $\begin{array}{l}\text { Availability statement, retrieval method, and } \\
\text { accessibility }\end{array}$ & $\begin{array}{l}\text { Empirical studies excluding } \\
\text { case studies and systematic } \\
\text { reviews/meta-analysis } \\
(\mathrm{n}=150)\end{array}$ & $\begin{array}{l}\text { Defines exact materials } \\
\text { needed to reproduce study }\end{array}$ \\
\hline \multicolumn{3}{|l|}{ Raw Data } \\
\hline $\begin{array}{l}\text { Availability statement, retrieval method, } \\
\text { accessibility, comprehensibility, and content }\end{array}$ & $\begin{array}{l}\text { Empirical studies excluding } \\
\text { case studies }(\mathrm{n}=150)\end{array}$ & $\begin{array}{l}\text { Provision of data collected in } \\
\text { the study to allow for } \\
\text { independent verification }\end{array}$ \\
\hline \multicolumn{3}{|l|}{ Analysis Scripts } \\
\hline $\begin{array}{l}\text { Availability statement, retrieval method, and } \\
\text { accessibility }\end{array}$ & $\begin{array}{l}\text { Empirical studies excluding } \\
\text { case studies }(\mathrm{n}=152)\end{array}$ & $\begin{array}{l}\text { Provision of scripts used to } \\
\text { analyze data }\end{array}$ \\
\hline \multicolumn{3}{|l|}{ Preregistration } \\
\hline $\begin{array}{l}\text { Availability statement, retrieval method, } \\
\text { accessibility, and content }\end{array}$ & $\begin{array}{l}\text { Empirical studies excluding } \\
\text { case studies }(\mathrm{n}=152)\end{array}$ & $\begin{array}{l}\text { Publicly accessible study } \\
\text { protocol }\end{array}$ \\
\hline \multicolumn{3}{|l|}{ Replication Study } \\
\hline $\begin{array}{l}\text { Is the study replicating another study, or has } \\
\text { another study replicated the study in question }\end{array}$ & $\begin{array}{l}\text { Empirical studies excluding } \\
\text { case studies }(\mathrm{n}=152)\end{array}$ & $\begin{array}{l}\text { Evidence of replicability of the } \\
\text { study }\end{array}$ \\
\hline
\end{tabular}

Table 2: Characteristics of Included Publications

\begin{tabular}{|c|c|c|}
\hline \multicolumn{2}{|c|}{ Characteristic } & $\mathbf{N}(\%)$ \\
\hline \multirow{4}{*}{$\begin{array}{l}\text { Test Subjects } \\
\qquad \mathbf{N}=\mathbf{2 9 2}\end{array}$} & Animals & $13(4.5)$ \\
\hline & Humans & $160(54.8)$ \\
\hline & Both & $2(.7)$ \\
\hline & Neither & $117(40.1)$ \\
\hline \multirow{4}{*}{$\begin{array}{c}\text { Country of } \\
\text { Journal } \\
\text { Publication } \\
\text { N=292 } \\
\end{array}$} & US & $178(61.0)$ \\
\hline & UK & $60(20.5)$ \\
\hline & Germany & $11(3.8)$ \\
\hline & Japan & $4(1.4)$ \\
\hline
\end{tabular}




\begin{tabular}{|c|c|c|}
\hline & France & $7(2.4)$ \\
\hline & Canada & $1(0.3)$ \\
\hline & Unclear & $10(3.4)$ \\
\hline & Other & $21(7.2)$ \\
\hline \multirow{12}{*}{$\begin{array}{l}\text { Country of } \\
\text { Correspondin } \\
\text { g Author } \\
\mathbf{N}=\mathbf{2 9 2}\end{array}$} & US & $105(36.0)$ \\
\hline & China & $17(5.8)$ \\
\hline & UK & $13(4.5)$ \\
\hline & Germany & $13(4.5)$ \\
\hline & Japan & $23(7.9)$ \\
\hline & France & $7(2.4)$ \\
\hline & Canada & $13(4.5)$ \\
\hline & Italy & $13(4.5)$ \\
\hline & India & $3(1.0)$ \\
\hline & Spain & $5(1.7)$ \\
\hline & Unclear & $2(0.7)$ \\
\hline & Other & $78(26.7)$ \\
\hline \multirow{4}{*}{$\begin{array}{l}5 \text { Year } \\
\text { Impact } \\
\text { Factor } \\
\mathrm{N}=292\end{array}$} & Median & 3.432 \\
\hline & 1st quartile & 2.319 \\
\hline & 3rd quartile & 4.334 \\
\hline & Interquartile range & 2.015 \\
\hline \multirow{3}{*}{$\begin{array}{c}\text { Most Recent } \\
\text { Impact Factor } \\
\text { Year } \\
\mathbf{N}=\mathbf{3 0 0}\end{array}$} & 2017 & 269 \\
\hline & 2018 & 1 \\
\hline & Not Found & 30 \\
\hline \multirow{4}{*}{$\begin{array}{l}\text { Most Recent } \\
\text { Impact Factor } \\
\mathbf{N}=\mathbf{2 7 2}\end{array}$} & Median & 3.504 \\
\hline & 1st quartile & 2.29 \\
\hline & 3rd quartile & 4.88 \\
\hline & Interquartile range & 2.59 \\
\hline
\end{tabular}


bioRxiv preprint doi: https://doi.org/10.1101/726505; this version posted August 9, 2019. The copyright holder for this preprint (which was not certified by peer review) is the author/funder, who has granted bioRxiv a license to display the preprint in perpetuity. It is made available under aCC-BY 4.0 International license.

Abbreviations: CI, Confidence Interval. 
Table 3: Indicators of Reproducibility in Pulmonology Studies

\begin{tabular}{|c|c|c|c|}
\hline \multicolumn{2}{|c|}{ Characteristics } & N (\%) & $95 \%$ CI \\
\hline \multirow[b]{8}{*}{ Funding $\mathrm{N}=\mathbf{2 9 2}$} & University & $6(2.1)$ & $0.5-3.7$ \\
\hline & Hospital & $3(1.0)$ & $0-2.2$ \\
\hline & Public & 37 (12.7) & $8.9-16.4$ \\
\hline & Private/Industry & $18(6.2)$ & $3.4-8.9$ \\
\hline & Non-profit & $5(1.7)$ & $0.2-3.2$ \\
\hline & No statement listed & $164(56.2)$ & $50.6-61.8$ \\
\hline & Multiple sources & $24(8.2)$ & $5.1-11.3$ \\
\hline & $\begin{array}{l}\text { No funding } \\
\text { received }\end{array}$ & $35(12.0)$ & $8.3-15.7$ \\
\hline \multirow{3}{*}{$\begin{array}{c}\text { Conflict of } \\
\text { Interest } \\
\text { Statement } \mathbf{N}=\mathbf{2 9 2}\end{array}$} & $\begin{array}{l}\text { Statement, one or } \\
\text { more conflicts of } \\
\text { interest }\end{array}$ & $50(17.1)$ & $12.9-21.4$ \\
\hline & $\begin{array}{l}\text { Statement, no } \\
\text { conflict of interest }\end{array}$ & $157(53.8)$ & $48.1-59.4$ \\
\hline & $\begin{array}{l}\text { No conflict of } \\
\text { interest statement }\end{array}$ & $85(29.1)$ & $24.0-34.3$ \\
\hline \multirow[b]{3}{*}{$\begin{array}{c}\text { Data Availability } \\
\quad \mathrm{N}=\mathbf{1 5 2}\end{array}$} & $\begin{array}{l}\text { Statement, some } \\
\text { data are available }\end{array}$ & $50(17.1)$ & $12.9-21.4$ \\
\hline & $\begin{array}{l}\text { Statement, data are } \\
\text { not available }\end{array}$ & $157(53.8)$ & $48.1-59.4$ \\
\hline & $\begin{array}{l}\text { No data availability } \\
\text { statement }\end{array}$ & $85(29.1)$ & $24.0-34.3$ \\
\hline \multirow[b]{3}{*}{$\begin{array}{c}\text { Material } \\
\text { Availability } \\
\mathbf{N}=\mathbf{1 5 0}\end{array}$} & $\begin{array}{l}\text { Statement, some } \\
\text { materials are } \\
\text { available }\end{array}$ & $16(10.7)$ & $7.17-14.2$ \\
\hline & $\begin{array}{l}\text { Statement, } \\
\text { materials are not } \\
\text { available }\end{array}$ & $1(0.7)$ & $0-1.6$ \\
\hline & $\begin{array}{l}\text { No materials } \\
\text { availability } \\
\text { statement }\end{array}$ & $133(88.7)$ & $85.1-92.3$ \\
\hline
\end{tabular}




\begin{tabular}{|c|c|c|c|}
\hline \multirow{2}{*}{$\begin{array}{c}\text { Protocol } \\
\text { Availability } \\
\mathbf{N}=\mathbf{1 5 2}\end{array}$} & Full Protocol & $2(1.3)$ & $0-2.6$ \\
\hline & No Protocol & $150(98.7)$ & $97.4-100$ \\
\hline \multirow[b]{3}{*}{$\begin{array}{l}\text { Analysis Scripts } \\
\qquad \mathbf{N}=\mathbf{1 5 2}\end{array}$} & $\begin{array}{l}\text { Statement, some } \\
\text { analysis scripts are } \\
\text { available }\end{array}$ & 0 & 0 \\
\hline & $\begin{array}{l}\text { Statement, analysis } \\
\text { scripts are not } \\
\text { available }\end{array}$ & 0 & 0 \\
\hline & $\begin{array}{l}\text { No analysis script } \\
\text { availability } \\
\text { statement }\end{array}$ & $152(100)$ & 0 \\
\hline \multirow{2}{*}{$\begin{array}{c}\text { Replication } \\
\text { Studies } N=152\end{array}$} & Novel study & $151(99.3)$ & $98.4-100$ \\
\hline & Replication & $1(0.7)$ & $0-1.6$ \\
\hline \multirow{5}{*}{$\begin{array}{c}\text { Cited by } \\
\text { Systematic } \\
\text { Review or } \\
\text { Meta-Analysis } \\
\text { N=180 }\end{array}$} & No Citations & $155(86.1)$ & $82.2-90.0$ \\
\hline & A Single Citation & $13(7.2)$ & $4.3-10.2$ \\
\hline & $\begin{array}{l}\text { One to Five } \\
\text { Citations }\end{array}$ & $11(6.1)$ & $3.4-8.8$ \\
\hline & $\begin{array}{l}\text { Greater than Five } \\
\text { Citations }\end{array}$ & $1(.56)$ & $0-1.4$ \\
\hline & $\begin{array}{l}\text { Excluded in SR or } \\
\text { MA }\end{array}$ & $1(.56)$ & $0-1.4$ \\
\hline \multirow[b]{3}{*}{$\begin{array}{c}\text { Preregistration } \\
\qquad \mathrm{N}=152\end{array}$} & $\begin{array}{l}\text { Statement present, } \\
\text { preregistered }\end{array}$ & $14(9.7)$ & $5.9-12.5$ \\
\hline & $\begin{array}{l}\text { Statement present, } \\
\text { not pre-registered }\end{array}$ & $3(2.1)$ & $0.4-3.5$ \\
\hline & $\begin{array}{l}\text { No preregistration } \\
\text { statement }\end{array}$ & $135(88.8)$ & $85.2-92.4$ \\
\hline \multirow{3}{*}{$\begin{array}{c}\text { Frequency of } \\
\text { Reproducibility } \\
\text { Indicators in } \\
\text { Selected Studies } \\
\mathbf{N}=\mathbf{2 9 2}\end{array}$} & $\begin{array}{c}\text { Number of } \\
\text { Indicators Present } \\
\text { in Study }\end{array}$ & & \\
\hline & 0 & $66(22.6)$ & - \\
\hline & 1 & $131(44.9)$ & - \\
\hline
\end{tabular}


bioRxiv preprint doi: https://doi.org/10.1101/726505; this version posted August 9, 2019. The copyright holder for this preprint (which was not certified by peer review) is the author/funder, who has granted bioRxiv a license to display the preprint in perpetuity. It is made available under aCC-BY 4.0 International license.

\begin{tabular}{|c|c|c|c|}
\hline \multicolumn{2}{|c|}{$2-5$} & $95(32.5)$ & - \\
\cline { 2 - 4 } & \multicolumn{1}{|c|}{$6-8$} & 0 & - \\
\hline \multicolumn{5}{|c|}{} & $\begin{array}{l}\text { Found via Open } \\
\text { Access Button }\end{array}$ & $\begin{array}{l}\text { Yes found article } \\
\text { via other means }\end{array}$ & 114 & - \\
\cline { 2 - 4 } $\begin{array}{c}\text { Open Access } \\
\mathbf{N = 2 9 2}\end{array}$ & $\begin{array}{l}\text { Could not access } \\
\text { through paywall }\end{array}$ & 80 & - \\
\hline
\end{tabular}




\section{Figure 1: Article selection and filtering process}

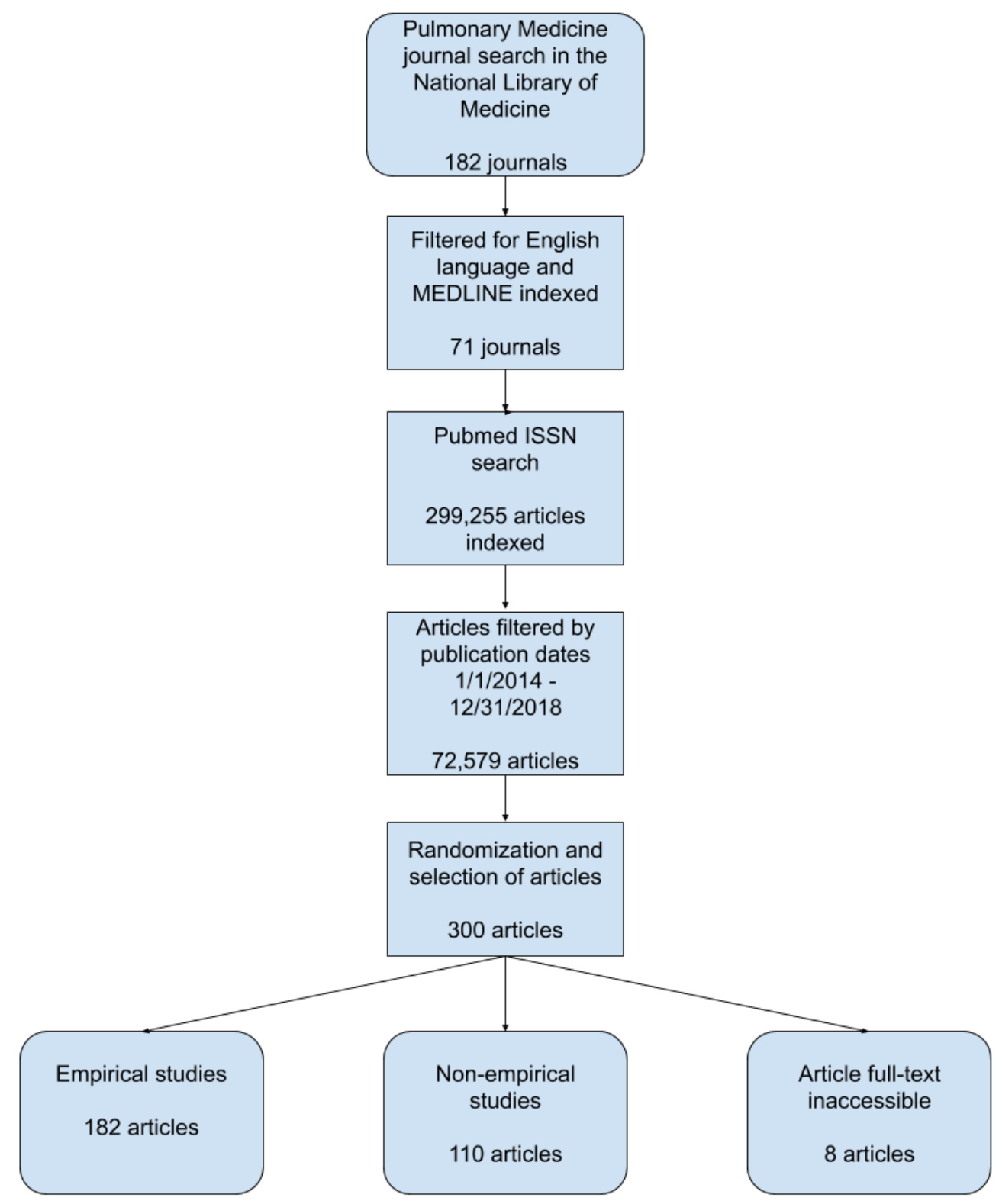


bioRxiv preprint doi: https://doi.org/10.1101/726505; this version posted August 9, 2019. The copyright holder for this preprint (which was not certified by peer review) is the author/funder, who has granted bioRxiv a license to display the preprint in perpetuity. It is made available under aCC-BY 4.0 International license.

Figure 2: Proportion of Studies with Reproducibility Indicators

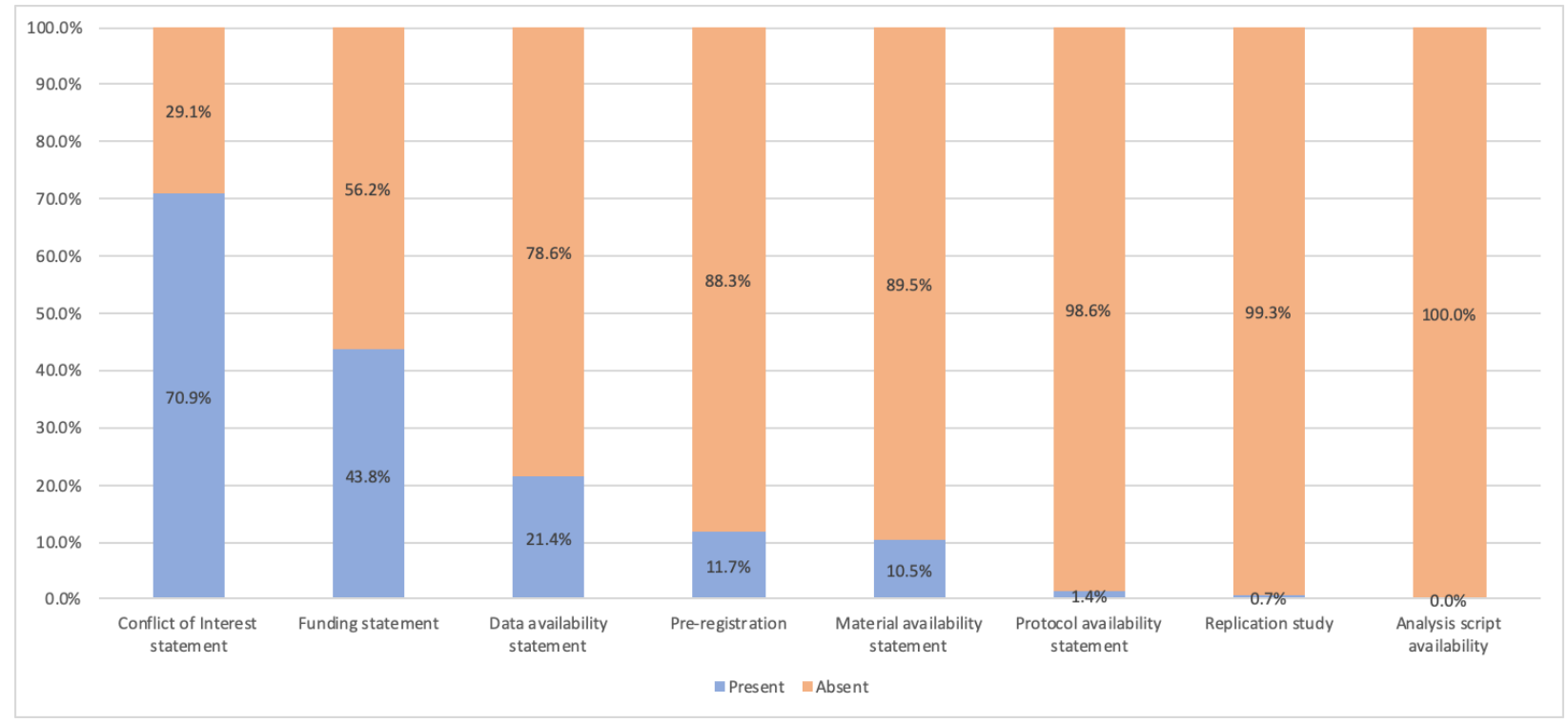




\begin{tabular}{|c|c|c|c|}
\hline \multicolumn{2}{|c|}{ Characteristics } & No. (\%) & $95 \% \mathrm{CI}$ \\
\hline \multirow{6}{*}{$\begin{array}{c}\text { Material } \\
\text { Availability } \\
\quad \mathbf{N}=\mathbf{1 6}\end{array}$} & Personal or institutional & 0 & - \\
\hline & $\begin{array}{l}\text { Supplementary } \\
\text { information hosted by the } \\
\text { journal }\end{array}$ & 11 & - \\
\hline & Online third party & 3 & - \\
\hline & Upon Request & 2 & - \\
\hline & $\begin{array}{l}\text { Yes, material was } \\
\text { accessible }\end{array}$ & 10 & - \\
\hline & $\begin{array}{l}\text { No, material was not } \\
\text { accessible }\end{array}$ & 6 & - \\
\hline \multirow[b]{12}{*}{$\begin{array}{c}\text { Data Availability } \\
\qquad \mathbf{N}=\mathbf{3 1}\end{array}$} & Personal or institutional & 1 & - \\
\hline & $\begin{array}{l}\text { Supplementary } \\
\text { information hosted by the } \\
\text { journal }\end{array}$ & 22 & - \\
\hline & Online third party & 5 & - \\
\hline & Upon Request & 3 & - \\
\hline & Other (b) & 0 & - \\
\hline & $\begin{array}{l}\text { Yes, data could be } \\
\text { accessed and downloaded }\end{array}$ & 25 & - \\
\hline & $\begin{array}{l}\text { No, data count not be } \\
\text { accessed and downloaded }\end{array}$ & 6 & - \\
\hline & $\begin{array}{l}\text { Yes, data files were } \\
\text { clearly documented }\end{array}$ & 25 & - \\
\hline & $\begin{array}{l}\text { No, data files were not } \\
\text { clearly documented }\end{array}$ & 0 & - \\
\hline & $\begin{array}{l}\text { Yes, data files contain all } \\
\text { raw data }\end{array}$ & 2 & - \\
\hline & $\begin{array}{l}\text { No, data files do not } \\
\text { contain all raw data }\end{array}$ & 10 & - \\
\hline & $\begin{array}{l}\text { Unclear if all raw data } \\
\text { was available }\end{array}$ & 13 & - \\
\hline
\end{tabular}




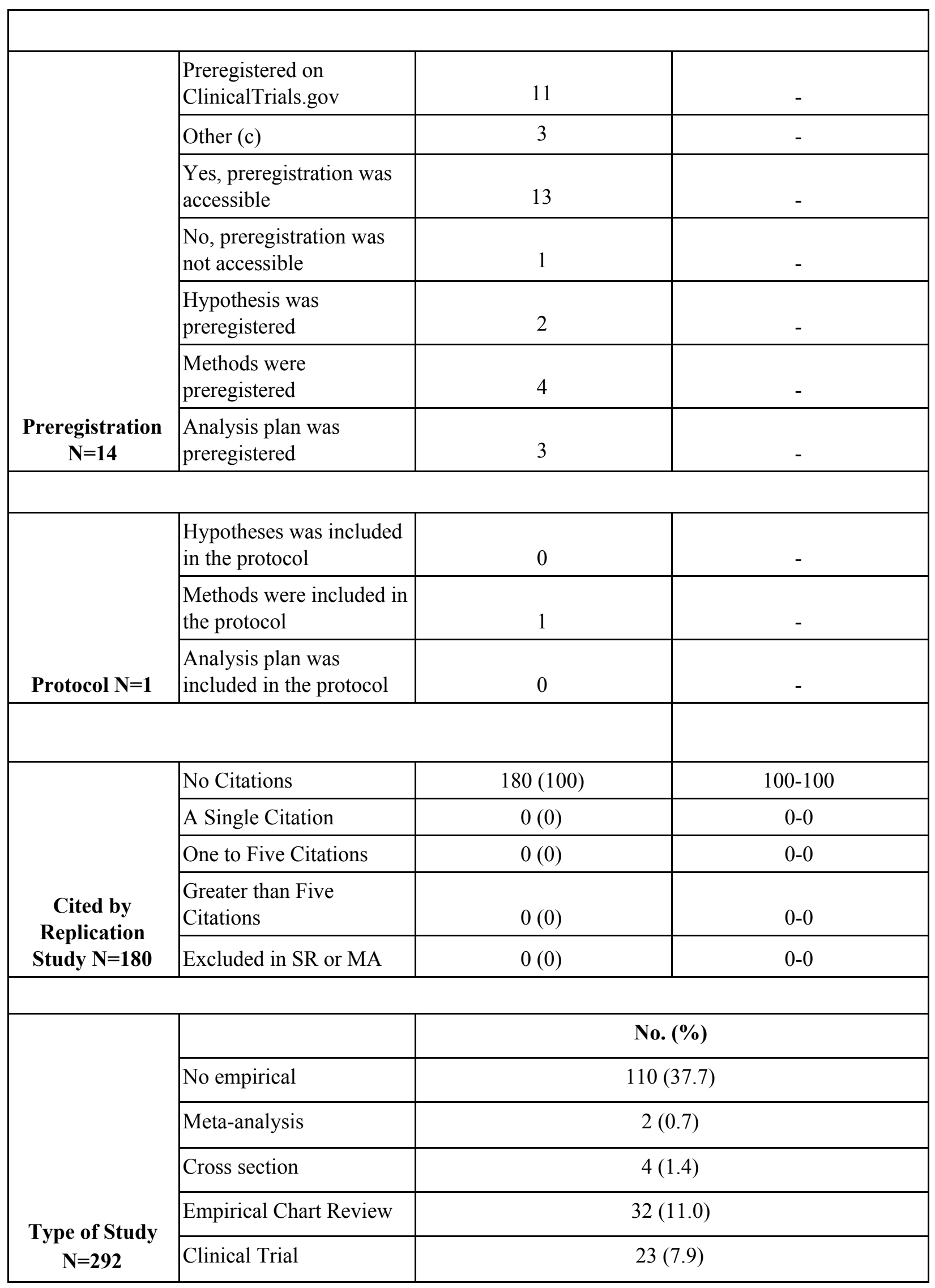


bioRxiv preprint doi: https://doi org/101101/726505: this version posted August 9, 2019. The copyright holder for this preprint (which was not certified by peer review) is the author/funder, who has granted bioRxiv a license to display the preprint in perpetuity. It is made available under aCC-BY 4.0 International license.

\begin{tabular}{|l|l|c|}
\hline Case study & $22(7.5)$ \\
\cline { 2 - 3 } Case Series & $8(2.7)$ \\
\cline { 2 - 3 } Cohort & $32(11.0)$ \\
\cline { 2 - 3 } Secondary Analysis & $4(1.4)$ \\
\cline { 2 - 3 } Case Control & $7(2.4)$ \\
\cline { 2 - 3 } Survey & $8(2.7)$ \\
\cline { 2 - 3 } & Laboratory & $32(11.0)$ \\
\cline { 2 - 3 } & Multiple & $1(0.3)$ \\
\cline { 2 - 3 } & Other & $7(2.4)$ \\
\hline
\end{tabular}

